\title{
The Development of Developmental Neuroscience
}

\author{
Carol Mason \\ Departments of Pathology and Cell Biology, Neuroscience, and Ophthalmology, Columbia University, College of Physicians and Surgeons, New York, \\ New York 10032
}

\section{Introduction}

Forty years ago in the emerging field of developmental neurobiology, neuroanatomists studied cellular development in their favorite brain region by annotating static Golgi preparations at different time points. Cell biologists examined how growth cones grow in tissue culture, probed how cells survived, and discovered nerve growth factor with clever embryological, culture, and biochemical methods, and tested the concept of specificity-that neurons connected to their targets through chemical affinitieshighlighted by Sperry's studies (Sperry, 1963) on the regenerating frog visual system. Hubel and Wiesel's enormous contribution to understanding how early experience affected visual behavior (Wiesel and Huber, 1965) set the stage for the now avidly studied topic of activity-dependent sculpting of wiring; but they could not address questions at the mechanistic level. None of these investigators circa 1969 considered themselves neuroscientists, let alone developmental neurobiologists. The first Society for Neuroscience meetings were small, and there was little focus on development, save for a trio of talks on critical periods in CNS development (by Colin Blakemore, Seymour Levine, and Alan Hein) at the first meeting in 1971. Not until the mid-70s was there a whole section of the program out of approximately 50 categories devoted to development and aging. By 1981, developmental neuroscience became more popular, and a section called "Development and Plasticity" was created. Annual Meetings were always so exciting when we heard firsthand about new paradigms during platform sessions where students and postdocs made their debut. We were taken aback by new categorizations of glia based on monoclonal antibody staining from Martin Raff's Special Lecture, and were intrigued by Martha Constantine-

Received Sept. 18, 2009; accepted Sept. 18, 2009.

This work was supported by the National Institutes of Health (National Eye Institute, National Institute of Neurological Disorders and Stroke), the Gatsby Foundation, Spinal Muscular Atrophy Foundation, and Human Frontier Science Program. I thank many colleagues, in particular, Moses Chao, Aniruddha Das, Barry Dickson, Fiona Doetsch, Stuart Firestein, Marie Filbin, Wes Grueber, Mary Beth Hatten, Andrew Huberman, Zaven Kaprielian, Eve Marder Jonathan Raper, Josh Sanes, and Carl Schoonover, for their recent conversations and input into this perspective. Because of the enormity of the subject, we chose to cite select reviews, commentaries, and references, and apologize for any omissions.

Correspondence should be addressed to Carol Mason, Departments of Pathology and Cell Biology, Neuroscience, and Ophthalmology, Columbia University, College of Physicians and Surgeons, 630 W. 168th Street, New York, NY 10032.E-mail: cam4@columbia.edu.

DOI:10.1523/JNEUROSCI.4648-09.2009

Copyright $\odot 2009$ Society for Neuroscience $\quad$ 0270-6474/09/2912735-13\$15.00/0
Paton's experiments on the three-eyed frog that tested the notion of competition.

In those days, one did not choose upfront to enter the field of developmental neurobiology. There were few reigning instructional guides. The "texts" were long and detailed articles (25 figures within the paper was the norm) written in descriptive but analytic style, and followed a time line. These were tighter than the diarist style of the 19th century naturalists, but contained rich accounts of morphology and cell biology; even the Journal of Cell Biology in the 70s allowed sections of papers to be called "Observations" (Tennyson, 1970). Now, we have an abundance of texts on development, some within neuroscience textbooks and others devoted to the subject, that try their best to merge history and current ideas from the flurry of journal publications (Patterson and Purves, 1982; Sanes et al., 2006). One can learn much from the many poignant autobiographical recollections of those who have worked on neural development, e.g., from those in the History of Neuroscience in Autobiography series, http://www.sfn. org/index.aspx?pagename $=$ HistoryofNeuroscience_main, by Victor Hamburger, Ray Guillery, Bernice Grafstein, Max Cowan, Mary Bunge, Lynn Landmesser, Nicole Le Douarin, David Hubel, and Torstein Wiesel, as well as other biographical accounts (Cowan, 2001). In addition, one can learn from articles recounting the trends of the previous decades (Reichardt, 1985; Cowan, 1998), a commentary on specificity (Easter et al., 1985), and a most engaging one published at the millennium (Jessell and Sanes, 2000).

Now, at the Annual Meeting we have an overwhelming sense of ignorance in trying to glean the newest information from the hundreds of posters in the Development section each morning and afternoon, flickering sound bites about expression of a new gene or manipulation of another gene. We consider ourselves victorious: many laboratories know how to genetically mark subsets of cells, use a dazzling array of cell culture and invasive molecular and genetic approaches to test the roles of an unending menu of molecular factors, and use the tools of the old anatomists - microscopes, but now laser-driven and digital— to peek at living neurons behaving in their native surroundings. But how much closer have we come to appreciating how growing axons and dendrites form synapses and create functional circuits, or how the neural tube and its emerging sectors are patterned into recognizable brain regions? Do we understand how specificity of synaptic connections is established? Have developmental studies 
contributed to solutions for injury or neurodevelopmental and neurodegenerative disorders? Here, I invite you to experience a "flight" - a tasting of what the field was like at the founding in 1969 of the Society for Neuroscience, where we are positioned after four decades of spectacular advances, and a forecast what is to come.

\section{The ever-expanding toolbox}

Over the last few decades, we have witnessed the emergence of a staggering array of new methods and tools for visualizing cells and pathways and following their development. We can isolate and cultivate neurons and tamper with molecular factors to deduce function. And we can hunt down genes, discovering many more than we can manage.

\section{Seeing is believing}

Thirty years ago, Victor Hamburger (1988) expounded the origins of the field of neural development, citing two streams, Histogenic Observation and Experimental Embryology. Of course there are no finer examples of the histogenetic approach to studying how neurons develop and connect with their targets than the studies of Ramon y Cajal (1911). These vivid accounts remain the starting point of every developmental analysis of various brain regions in the vertebrate nervous system. Neuroanatomists of the $60 \mathrm{~s}$ and 70s who followed in Cajal's footsteps annotated static Golgi preparations with exacting camera lucida drawings, and carefully gleaned principles of cell structure and synaptic connections in thin sections of unlabeled tissue using electron microscopes. These marvelously evocative accounts told the story of how the cellular components of a brain region are elaborated, and even made inferences about mechanisms.

In the late $60 \mathrm{~s}$, information about connectivity in the mature brain was deduced through lesions followed by silver stains (Nauta, 1993); but these methods were rarely applied to developing systems, because the stains were based on silver reactions with neurofilaments and degenerating myelin, which are in short supply in developing axons. By the 70s injection and transport of tritiated amino acids gave a more holistic and accurate view of normal projecting axons, and revealed the pruning that occurs during the formation of ocular dominance columns (LeVay et al., 1978). In the 70s, tracers such as horseradish peroxidase (HRP) were injected into target areas, and retrograde transport of these tracers or fluorescently labeled beads (Katz and Iarovici, 1990) localized the somata of cells that innervated different regions. Similarly, anterograde transport provided Golgi-like, fulsome revelations of entire axon arbors (Mason, 1982a).

Electron microscopy (EM) provided a means of studying synaptic connections, given that we knew the morphology and dimensions of neurons from Golgi preparations. After bulk labeling axons with HRP and studying their morphology, synaptic relationships could then be studied by examining details of axons arbors in the light microscope followed by ultrastructural analysis (Mason, 1982b). While this method was very labor-intensive, new methods for serial section electron microscopy (with or without markers) and EM tomography (Luo et al., 2008), while also laborious, should help us unravel the fine structure of developing circuitry.

Undoubtedly the biggest boon to developmental studies was the discovery in the late 80 s of tracers that could be precisely applied in minute quantities to fixed tissue. These tracers outlined the early phases of axon outgrowth and developing pathways with single-cell resolution in embryos (Godement et al., 1987). DiI (I,I-dioctadecyl-3,3,3', 3' -tetramethylindocarbocyanine perchlorate) and its analogues are lipophilic carbocyanine com- pounds that move within the lipid bilayer of the membrane and are never completely fixed by aldehydes. Although DiI works poorly on myelinated axons, DiI-filling of neurons in all their glory freed us from the capriciousness of the Golgi technique, which labels random cells without experimenter control. We readily saw growth cones in their natural paths, and deduced behaviors that led to forays into unraveling developmental steps and mechanisms (Godement et al., 1990). And of late, tracers such as cholera toxin allow pathways to be charted in latedeveloping rodents, when DiI is no longer effective (Huberman et al., 2008). These tracing methods initiated a renaissance in neuroanatomical and developmental methods (Cowan, 1998).

Immunohistochemistry approaches opened another floodgate of knowledge, and helped to unveil cell relationships and developmental principles in a variety of species (Reichardt, 1984). The development of monoclonal antibodies that labeled single epitopes was especially important and provided markers (TOP antigen) for polarity in the retina (Moskal et al., 1986), which presaged the later discovery of gradients of Ephs and ephrins in the retina and tectum and other targets, defined anterior-posterior poles of the embryo (Kaprielian and Patterson, 1993), and highlighted previously unknown cell types (Hockfield, 1987). These tools also paved the way for studies of neurogenesis, cell lineage, and axon guidance in the simple nervous system of the insect (Goodman et al., 1984). In one of the Society's first short courses, "New approaches in Developmental Neurobiology" in 1981, four of the 11 lectures were devoted to the production of monoclonal antibodies. Although many of these antibodies are still in use, the refinement of polyclonal antibodies, which are made purer by immunoabsorption, are now in as much use as monoclonals. Unfortunately, many commercially available antibodies have proven to be nonspecific for even the simplest of proteins and this has delayed progress in localizing many proteins such as growth and guidance factors. As a result, most researchers have resorted to localizing the mRNA of a particular protein by in situ hybridization.

\section{Marking cells through molecular genetics}

So much has advanced in cell marking and gene perturbation through molecular genetics. Forty years ago we would have never dreamed of these possibilities! Astounding achievements have come recently from genetic insertion, either intentionally or serendipitously, of fluorescent proteins and other markers into select genes (Luo et al., 2008). Expression of green fluorescent protein (GFP) under the control of cell-type specific promoters and enhancers can be used to label specific subsets of cells. Using bacterial artificial chromosomes (BAC) to replace the endogenous protein coding sequence of a gene of interest with the sequence for EGFP (Heintz, 2001; Luo et al., 2008) reveals not only cells that express the gene, but also cells that are putatively similar or harbor a gene with the same regulatory sequences, results in the marker being expressed in a small percentage of neurons, and yields an inheritable Golgi-like effects that reveals the entire morphology of the cell. The most dazzling example of this is the Brainbow mouse, in which distinct mixtures of just three fluorescent proteins are expressed in individual neurons and, after several rounds of recombination, chance expression of the fluorescent proteins in varying concentrations in different neurons creates dozens of hues, producing color-coded Golgi-like labeling (Livet et al., 2007). Using similar transgenic techniques to label specific populations of neurons with precise spatial and temporal control has been a boon for mapping the fate of developing neurons (Miyoshi and Fishell, 2006). This approach showed, for example, that cortical interneurons come from a foun- 
tainhead in subcortical (ganglionic eminence) regions, migrate long distances to the cortex, and can be grouped by transcription factor expression and physiological responses (Butt et al., 2005).

\section{Microscopes-lights, action}

The changes in the ways we visualize cells by intentionally labeling them are astonishing, and so are the improvements in the instruments through which we see them. In the 70s, time-lapse microscopy provided Wessells and Letourneau with their important first views of growth cone behavior using $8 \mathrm{~mm}$ cine film (Letourneau, 1975). Later, simple inverted microscopes with fluorescence illumination and analog video cameras provided the first views of growth cones navigating and exploring targets (Harris et al., 1987; Godement et al., 1994; Hutson and Chien, 2002). Since then, basic modes of transmitted light and electron microscopy have remained the same, but digital cameras now eliminate both the long exposures to illumination that would kill cells and the painstaking hours in the darkroom. Confocal and multiphoton microscopy now allow us to see fine details well below the surface of fixed tissue as well as in living preparations, and to reconstruct and rotate stacks of images in three dimensions. With our current abilities, we can see axons and dendrites growing and retracting, and see spines and synaptic boutons dancing in place, extending, withdrawing (Bonhoeffer and Yuste, 2002), and even distinguish synaptic receptors and presynaptic or postsynaptic specializations (Marrs et al., 2001). Nonetheless, the development of microscopical techniques is outpacing the ability of investigators to carry out such studies, which require the patient, observational style of the classic neuroanatomists to document the unfolding processes.

\section{Reductionist and experimental: tissue culture}

Even though he named the budding tips of developing axons and dendrites "growth cones" when he analyzed them in static preparations, Cajal never observed growth within living tissue. Harrison (1910) developed tissue culture techniques, and Spiedel (1933) witnessed living growing neurites through the thin skin of a tadpole. But it was not until 1975, when cell biologist Norm Wessells and his student Paul Letourneau placed neurons in tissue culture, that anyone could demonstrate what Cajal predicted: that neurons have likes and dislikes in what they grow on (Letourneau, 1975). This work set the stage for many insights and assays in the extraordinary studies of axon guidance to come, such as turning assay in which substances were puffed onto growth cones (Lohof et al., 1992), graded and striped substrates (Walter et al., 1987) to test growth cone preference, and cell purification followed by select recombinations to test cell autonomous effects (Hatten et al., 1986). The Campenot chamber made it possible to test factors on distal axons without affecting the cell body and revealed that growth factors are retrogradely transported (Watson et al., 2001). It is curious that even though cold-blooded amphibian and fish preparations could be kept for many days intact or isolated, most culture models use tissue or on cell lines derived from humans, chicks, or rodents. Nevertheless, it came as a surprise that slices and even whole embryos of rodent brain could be cultured and used to reveal many principles in all phases of development (Polleux and Ghosh, 2002). In all, culture approaches paved the way for the molecular experimentation that is our mainstay today.

\section{Molecules, and perturbing molecules}

The mid-90s brought the molecular revolution to developmental neurobiology. With the knowledge that events occur at specific times, that sequences unfold in a certain order, and that molecules can stimulate or inhibit growth of cultured neurons (Patterson, 1988), we used immunohistochemical and in situ hybridization methods to see whether members of the small set of previously discovered families of guidance factors were expressed in the right place and time to mediate these effects in vivo. One approach was to identify molecules that were expressed specifically in the sites where pathway choices were made. We hoped to find gradients of factors that could guide formation of topographical maps by growing retinal ganglion cell axons, or that might mediate the growth of commissural axons toward the ventral, but not dorsal, spinal cord, or toward a congregation of neuroepithelial cells at the midline called the floor plate. For the latter, brute force biochemistry, followed by culture assays and localization yielded netrin, one of the first guidance molecules identified that orients growth, luring some axons and repelling others. Once there was a hint of molecular expression at a certain site, we aimed to knock out the gene of interest and analyze the phenotype.

The other route, now used routinely in forward genetic screens by fly and worm geneticists, was to analyze mutants displaying disruptions of developmental processes or cellular morphology and then clone and identify the gene. In the 70s and 80s, using the histogenetic approach, Richard Sidman and Pasko Rakic, and Constantino Sotelo in France, made a major leap in understanding the development of brain regions such as the cerebellum and cortex by analyzing the storehouse of naturally occurring mutants cataloged by The Jackson Laboratory. They deduced cellular interactions and dependency from mutants in which cells were missing or had defective migration and cell-cell relationships (Rakic and Sidman, 1973). Notable among these were abnormalities seen in the weaver, reeler, and staggerer mutants. At the time, deductions regarding the site of gene action were not always on the mark. The genes for these mutants and others have now been cloned [e.g., for weaver, see the study by Kofuji et al. (1996)], but it is still difficult to comprehend how a mutation in any one of these genes in specific cell types could cause the severe brain disruptions found in these mutants, or in the albino, in which mutations in genes for melanin synthesis in the eye cause misrouting of visual projections (Guillery et al., 1974, 1995).

Once molecular tools became available, methods were developed to perturb the molecules and read the consequences, to deduce function. Tampering with genes and proteins to analyze molecular mechanisms have become the norm, requiring multimodal, multicollaborative efforts. We eliminate molecules through single, double, and triple knockouts and by barring RNA translation using RNA interference. We block function with antibodies or dominant/negative forms. We also create conditional knockouts, whereby a gene is deleted in a particular region or cell, at precise times, by regulating expression via a transactivator (tTA) driven by a distinct promoter or by site-directed recombination (e.g., $\mathrm{Cre}^{\mathrm{ER}}$ ) (Luo et al., 2008). Using transgenic technology on the whole animal or gene delivery by viruses or electroporation, a gene of interest can be added back to rescue a deletion phenotype or can be expressed prematurely or in an ectopic location. After a mutant line is developed, downstream signaling pathways can be probed, from the membrane to the actin cytoskeleton to the nucleus, to study transcriptional effects. With our new-found ability to pinpoint transcription factors in the last few years, we entered the domain of true molecular biologists (Qiu and Ghosh, 2008).

With this marvelous world at hand, though, we are now required to make a complete story about the molecular factors under study. Gone are the days when we can publish a paper describing a single axon trajectory that suggests the presence of both inhibitory and attractive growth (Tosney and Landmesser, 1985) or a description of growth cone behavior in culture (Kapfhammer and Raper, 1987). We must now identify the molecules involved or execute a panoply of analyses on the subject. 
Hunting for genes

In addition to cloning the genes from mutants found in screens or through histogenetic or other phenotype analysis, all routes are open for gene discovery, with the development of microarray technology in the last decade. A fruitful effort was mounted to seek activity-dependent changes in gene expression in the visual pathway, revealing the surprising link between activity and elements of the Major Histocompatibility Complex I in sculpting synaptic connectivity (Corriveau et al., 1998) and a poorly known adhesion molecule in mediating the formation of binocular circuitry through to the cortex (Leamey et al., 2007). Now we can use ChipSeq to identify tissue-specific enhancers, use arrays for microRNAs, and examine cell-specific expression of mRNAs (Doyle et al., 2008). Nothing is ever easy, however, because gene profiling, even of single cells, has unveiled great heterogeneity of gene expression in similar neuronal cell types (Sugino et al., 2006; Trimarchi et al., 2008).

\section{The phases of neural development: discoveries and lingering questions}

Now for a roll call of the phases of neural development and advances therein. Here I list some interesting threads and critical findings from the last forty years.

\section{Early neural development and regional specification}

In 1969, the molecular factors control neuronal fate were unknown, but the work of Melton and Hemmati-Brivanlou (1997) gave a molecular language to Spemann's findings on the organizer and induction of neural identity. Although earlier embryological studies of the neural tube revealed physical subdivisions that give rise to the forebrain and hindbrain, the discovery that different families of transcription factors were expressed in known and new subdivisions of the developing brain (Rubenstein et al., 1994) or in different poles of the cortex (O'Leary et al., 2007) supported the idea of regional identity. Now we can enumerate the genes that define a coordinate system that produces, for example, the dorsoventral axis of the spinal cord (Jessell, 2000), diversification of motor neuron columns (Dasen and Jessell, 2009), and the laminar structure, foliation, and molecular organization of the cerebellum (Sillitoe and Joyner, 2007).

\section{Neurogenesis, migration and specification of cell fate}

Sauer and others in the 30s outlined the steps in cell division in the neural tube, and showed that the nucleus moved from the pia to the ventricular zone, where it divided, then moved outward again to repeat the cycle (Sauer, 1935). Richard Sidman (Miale and Sidman, 1961) then developed a technique for marking cells undergoing mitosis with tritiated thymidine. Using this technique in combination with $\mathrm{x}$-irradiation to block division, many laboratories, notably Joseph Altman's, charted neurogenesis in almost every region in the rodent brain. Nowakowski and Caviness (Takahashi et al., 1996) then used a more refined method for charting neuronal proliferation; they measured the length of the cell cycle and the proportion of cells leaving the cell cycle, and found that neurons that migrate to a particular cortical layer have similar cell cycle parameters.

These studies made way for clonal analysis of neurons and glia, still an area of active study. Horseradish peroxidase was used by Jacobson in the very early frog embryo (Jacobson and Hirose, 1978) and later by Harris and Holt in the retina, then viral labeling methods were developed by Connie Cepko's laboratory. Surprisingly, a common progenitor was found to spawn clones composed of different cell types (Holt et al., 1988; Walsh and Cepko, 1988). Enlightening transplant experiments in the late 80s tested when a cell became committed to a particular fate, its laminar residence in the cortex relative to its birthday, and when its fate can no longer be changed (McConnell, 1988). A highlight from such studies was to see that upon cell division, proteins are distributed asymmetrically, and this determines cell polarity and/or cell fate (Doe, 1996). Other studies have implicated Notch signaling in directing neuronal versus glial fate (Gaiano and Fishell, 2002).

The 80 s brought video microscopy of cells in culture, which provided new views of how neurons migrated, inchworm style, and revealed that neurons need radial glia as struts. These ideas were emphasized by dynamic views of the weaver mouse mutant in which neurons cannot migrate along disheveled glia (Hatten et al., 1986) as was inferred previously from histogenetic observation (Rakic and Sidman, 1973). Then, only a few years ago, another seismic shift occurred: with cell marking methods and dynamic imaging, neurons were seen to arise directly from radial glial cells in the ventricular zone (VZ) (Noctor et al., 2001) and not separately, a heretical view to many.

These studies of neurogenesis and neuronal fate were accompanied in the late 90 s by studies on naturally occurring mouse mutants or ones in which the genes that were discovered to cause human cortical malformations were knocked out, such as doublecortin, mutated in human X-linked lissencephaly (Gleeson et al., 1999). Imaging and molecular studies continue to reveal the inner workings of migrating cells that power the cell body to translocate as the cell migrates (Solecki et al., 2009). A remaining conundrum is what signal the cell recognizes as it takes residence in its home layer or region (Sauer, 1953).

In a parallel effort, the most surprising, and at first, intensely debated, discovery regarding neurogenesis was that it can occur in adult brain. In the late 90s Doetsch and Alvarez-Buylla found that there are stem cells in the adult brain that have glial properties (Doetsch et al., 1999). Adult neurogenesis occurs in the subventricular zone (SVZ) of the mammalian brain, from which neurons migrate to the olfactory bulb, and in the subgranular zone (SGZ) of the hippocampal formation. These zones appear to be regionally specialized, and triggers of cell proliferation in the SVZ are being identified (Cheng et al., 2009; Kriegstein and Alvarez-Buylla, 2009). From studies in which these cells are labeled with retroviruses and fate mapped, we also know that the cells functionally integrate into the adult brain (Toni et al., 2008). And as if this were not enough, the vasculature in the SVZ has been reported to serve as a microniche for precursors that are ripe for transiting into neurons. These precursors nudge up in direct apposition to the vessels where they can most certainly perceive blood-borne signals (Tavazoie et al., 2008). The challenge presented by these huge discoveries of neurogenic events in young and developing brain include identifying the full repertoire of gene expression that coaxes embryonic stem cells or other progenitors into becoming identified subpopulations of neurons, which is being done for motor neurons (Wichterle et al., 2002).

\section{Cell specification}

Although we now think of cell specification as a new subject driven by the knowledge of genes that direct cell fate, forty years ago, many experiments examined the role of the environment in determining cell identity. The elegant and precise experiments of Nicole Le Douarin in the 70s on the influence of position on the outcome of transplanted neural crest cells (Le Douarin et al., 1975), and the culture experiments by Storey Landis and Paul Patterson on the factors that influence a cell to express noradrenergic or cholinergic neurotransmitters (Wolinsky et al., 1985) set 
the stage for thinking that the identity of a cell was in many ways scripted but malleable.

In the mid-90s, another shift in our view took place: unique combinations of transcription factors are expressed in different cell classes over the course of development. We now believe that these gene codes specify cell fate: for example, whether a neural precursor becomes an interneuron or a motor neuron (Jessell, 2000), or becomes a retinal ganglion cell instead of an amacrine cell ( $\mathrm{Li}$ et al., 2004). And we now readily accept that the worm is like a human: a conserved regulatory logic of transcription factor expression applies to dopamine neuron terminal differentiation in both species (Flames and Hobert, 2009). This arena should continue to provide fruit, revealing how transcriptional programs specify not only cell fate but also direct migration and axon outgrowth along specific routes (Polleux et al., 2007).

\section{Finding their way: axon guidance}

The star of the developing neuron is the growth cone. Christened by Cajal, and studied in vitro and in vivo with new dyes and imaging techniques, we know much about its activities and likes and dislikes as it guides the growing axon by perceiving both good and bad signals in its environment, enabling the axon to respond in kind. Culture studies indicated that filopodia were the sensing structures, and that extracellular matrix components were important for adhesion, but there was no information available in the early 70 s on what molecules indicated direction. In the 70 s Singer et al. (1979) proposed that there were channels between epithelial cells through which axons coursed, providing a blueprint for growth. The idea of physical conduits serving to guide axons did not take hold, however, and instead studies of labeled cells fortified the notion that the first axons to grow used surrounding cells as guides and later axons grew along their mates, forming bundles. These discoveries laid the groundwork for work on adhesion and fasciculation and identifying the molecules that implement these processes (Jessell, 1988).

In the late $60 \mathrm{~s}$, many believed that figuring out how simple circuits in invertebrates produce a simple behavior, where single identifiable neurons provide the inputs and outputs, would illuminate how vertebrate circuits function. Corey Goodman argued further that it was possible to use such simple systems to follow neurogenesis and axonal pathfinding in identified cells (Goodman et al., 1984). After establishing that the neurons in the same locus had similar forms from animal to animal and could be located time and time again, he showed that the choices these identified neurons made as they navigate are also stereotyped, and that extension was directed. These landmark studies gave credence to using the invertebrate simple systems for asking how neurons developed, especially during axon guidance, and with the power of fly and worm genetics, provided a setting for identifying the molecular nature of a myriad of guidance cues, signaling molecules, and transcription factors that control many aspects of development.

In the 80 s, the insect limb provided a graphic stage for viewing how the very first axons grow: sensory neurons contact a series of other cells, the guidepost neurons, and perceive information about where not to grow and where to extend toward the CNS (Caudy and Bentley, 1986). Although there were intimations of molecules used for adhesion or avoidance of growth, such as the fasciclins in the Ig-superfamily (Jessell, 1988), few factors that provide directional information had been identified. Then, several laboratories began to dissect the different influences of cells along the path of growing axons in vertebrate systems in vivo, such as the growth of dorsal-residing commissural neurons ventral and across the midline through the floor plate, which is com- prised of neuroepithelial cells spanning the ventricle to the pia. The collagen gel assay indicated that factors emanating from the floor plate attracted commissural axons to that spot, and that these factors were secreted and axon guidance did not require contact with the midline cells (Tessier-Lavigne et al., 1988). This and many other studies suggested four categories of axon growth: contact mediated or diffusible cues, evoking positive or negative effects. These remain the canonical foursome of guidance effects, and growth cones likely rely on all four mechanisms (TessierLavigne and Goodman, 1996). Marc Tessier-Lavigne then isolated the substance that was lured axons to the floor plate by biochemical isolation from thousands of chick spinal cords, and named it netrin. Thereafter he found an unlikely receptor for netrin, Deleted in Colorectal Cancer (DCC). And just as this work emerged around the mid-90s, genetic analysis revealed that UNC-6 was a conserved molecule with the same function in worm commissural neurons (Culotti, 1994; Serafini et al., 1994). What followed thereafter was a virtual explosion of work that characterized more guidance factor families and receptors-the Slits and Robo receptors, Semaphorins and neuropilin and plexin receptors, and the receptor tyrosine kinase Ephs and ephrins, identified through genetic analysis in flies and worms, by good detective work in higher organisms, and by matching expression of orphan receptors to scenarios in vivo, respectively (Huber et al., 2003).

The field continues to explore the action of these four guidance factor families, along with Ig-CAMs and extracellular matrix molecules such as laminin, the "original" molecular systems implicated in the simplest form of growth, axo-axonal and axo-basal lamina adhesion in developing systems of many species. Other guidance factors have been added to the list, the most surprising being morphogens such as Shh, BMPs, and Wnts (for example, see Butler and Dodd, 2003; Sanchez-Camacho and Bovolenta, 2008). Many of these guidance families may work in concert, such as when slit receptors silence netrin receptors to allow commissural axons to exit the spinal cord midline (Stein and TessierLavigne, 2001) or when IgCAMs collaborate with Semaphorin receptors to enable commissural growth in the forebrain (Bechara et al., 2007). To make for more complexity (and more elements to consider for a given guidance decision), molecular systems that are not canonical guidance factors may also play roles: for example, the cytokine SDF appears to mollify responses to semaphorins (Chalasani et al., 2003).

A major advance in our thinking on axon guidance is that transcription factors regulate guidance receptor and cue expression. Very recent work has shown that sets of transcription factors designate programs of guidance to different poles of the same region, as in dorsal and ventral limb mesenchyme (Luria et al., 2008); to different sides of the midline, as in retinal ganglion cell projection at the optic chiasm (Herrera et al., 2003); or to grossly different pathway choices, such as callosal versus corticospinal projections (Leone et al., 2008). How is this accomplished? Transcription factors direct guidance receptor expression, or, in the spinal cord, modifiers of receptor action (Wilson et al., 2008)all part of the score of the symphony of transcriptional activation and repression of genes during circuit formation, starting with cell specification and progressing to axon guidance.

The field of axon guidance has progressed very rapidly, but we are not there yet in understanding how axons grow: What controls the precise timing of transcription factor expression that in turn regulates the exquisitely controlled and discontinuous expression of cues and receptors, in some sort of magical forest of twinkling guiding lights? Are receptor proteins translated in the cell body and/or locally in the growth cone (Lin and Holt, 2008)? 
What are the signaling pathways from membrane to cytoskeleton that effect collapse or extension or turning? We know that commissureless and Rig-1/Robo3 proteins reign in Robo receptors at points where Slits are, to provide a pass to cross the midline (Dickson and Gilestro, 2006), but even with our cell biological and imaging prowess, how receptors are trafficked and degraded in the growth cone as they interact with the discontinuous hotspots of cue expression along a path is not understood.

\section{Dendrites}

For over 100 years, from a myriad of studies based on Golgi, cell-specific, and other genetic marking approaches, we have come to appreciate a stunning variety of dendritic shapes of neurons in every species. Histogenetic studies charted the development of dendrites, and found that some cells, like the Purkinje cell, initially form a "koosh ball" of short processes, then withdraw those and put out thicker branched trees. Culture studies in the 80 s showed how the cell forms an axon and by default, other processes become dendrites (Dotti et al., 1988). The influence of neurotrophins as well as synaptic inputs in shaping dendrite development continues to be shown beautifully in single-cell labeling and cell-perturbation studies (McAllister et al., 1999; Shen et al., 2009). Quite astonishing is that retinal ganglion cells display a huge variety of dendritic shapes (Kong et al., 2005). What genes regulate the cytoskeleton and dendritic process outgrowth to yield such different forms? And most remarkable is the discovery that dendrites of the same neuron do not become entangled because of a single splice form of DS-CAM out of many possible thousands, and that homotypic interactions of this splice form causes repulsion of one branch of a dendrite from another (Corty et al., 2009).

\section{Synapses}

Electron microscopy showed us how synapses in every reach of the nervous system were structured, but much of what we learned about synapse development has come from studies on the neuromuscular junction. An innervating nerve can induce cholinergic receptors to aggregate (Fischbach et al., 1978), and agrin was identified as the factor that performs this function. Thirty years later, we know many factors that designate where and when a synapse should form, in a give-and-take involving agrin signaling from the nerve to MuSK, part of the agrin receptor, rapsyn as an effector, and the dystrophin-glycoprotein complex and its cytoplasmic component, $\alpha$ dystrobrevin, to modulate maturation and maintenance of the postsynaptic apparatus (Sanes et al., 2001). A recent surprise was that a low-density lipoprotein receptor, Lrp4, has been found to be the long-sought receptor for agrin (Kim et al., 2008).

For many years the factors, both molecular and cell behavioral, that instigated CNS synapse development were acknowledged to be different from those at the neuromuscular junction, but what are they? Good cell biology brought the identification of neuroligins on the postsynaptic and neurexin on the presynaptic cell (Scheiffele et al., 2000), which implement the first step in triggering adhesion of two cellular partners and assembly of a synapse. A host of other elements are now known to be comprised in the presynaptic and postsynaptic side of both excitatory and inhibitory synapses (Waites et al., 2005). Growth cones were reported to spew out neurotransmitter while growing (Hume et al., 1983), but we still know little about the transformation of the growth cone to a synaptic bouton. Recent live imaging allowed us to view cell-cell interactions as axon endings contact dendritic protrusions: calcium transients fire as axonal tips contact dendritic filopodia during excitatory synapse formation, but not when GABAergic axons make synapses on that cell (Lohmann and Bonhoeffer, 2008). The discovery that molecules from the immune system modulate synapse formation (Corriveau et al., 1998 ) illustrates that synapse formation and refinement between two neurons is more complex than we thought.

\section{Dendritic spines}

The last 10 years of cell marking and imaging has brought a flood of studies on spines, the small protrusions that receive excitatory synaptic input. Spines were annotated by Cajal, and in the 70 s Purpura noted that their malformation reflected disorders such as mental retardation (Purpura, 1974). Now we know, as Crick predicted in the $80 \mathrm{~s}$, that spines move and twitch, extend and retract, expand their heads, and do all of this more during development (Bonhoeffer and Yuste, 2002). We have learned that spine motility is actin based and kept in check by glia, reflects calcium dynamics and receptor internalization, and that machinery for local protein translation is in place intracellularly-in sum, spines are targets for learning, plasticity, and disorders at every age. Still unresolved, however, is how spines emerge: through contact of the dendritic shaft by afferents, or de novo, waiting for an afferent to appear (Moltmaat and Svoboda, 2009)?

\section{Wiring up the brain: neuron-to-neuron matching during} circuit formation

When the Society began, one of the most influential undercurrents for developing and mature nervous systems alike was that neurons had factors that helped them recognize and connect with other neurons, to form specific synaptic connections. Roger Sperry brought back Cajal's idea that neurons had chemical affinities for specific paths of growth, and proposed a system of complimentary chemical factors that would enable both regenerating and developing axons to locate their site of termination. Before the Society started, Sperry, working with Attardi, showed that regenerating retinal axons can accurately find and innervate their original target locations in the frog tectum even after an eye was rotated (Attardi and Sperry, 1963; Sperry, 1963). Gaze and Jacobsen later excised parts of the retina or tectum, and showed that retinal axons can adapt to a reduced tectum or innervate the normal part of the tectum of the remaining eye (Gaze et al., 1965), indicating that axons indeed recognize labels on the tectal cells. Many have interpreted these labels to be as diverse as the cell types that form the multitude of connections in the nervous system (Easter et al., 1985), and Sperry himself worried that the number of tags would be unending (Grafstein, 2006).

The idea of selective synapse formation between afferent and target was studied extensively in the 70s with elegant experimental embryological experiments in vivo and in other settings by Purves, Lichtman, Thompson, and Landmesser and colleagues, on motor neuron innervation of limb muscles and preganglionic innervation of sympathetic ganglia (Landmesser, 1980). Such experiments showed that in the limb, afferents establish connections with their proper target even if the anterior-posterior axis was rotated.

This work simulated a search, still ongoing, for labels for the formation of specific synaptic connections. To date, few labels or markers for connections between specific axons and sets of target cells have been found. Gerald Edelman (1983) posited that NCAM was a crucial element for constructing brain circuitry via adhesion and its modulation, rather than by "strict chemoaffinities." This idea did not gain favor. Now CAMs are back in the limelight and we are delighted to see that the same IgCAM is expressed in subsets of synaptically linked cells across retinal layers indicating a system of biases and matching labels (Yamagata and Sanes, 2008), but not via the myriad of molecules that Sperry's initial thinking intimated. 
In the mid-80s, an ex-physicist turned molecular biologist, Friedrich Bonhoeffer, decided to probe further into Sperry's model of retinotectal mapping and identify the molecules that implemented mapping. Bonhoeffer hypothesized that there might be factors arrayed in a gradient on the tectal surface, and devised clever and precise culture assays - microstripes stripes of membranes from different poles of the targets - to test this hypothesis. Different parts of the chick retina (nasal or temporal) were given a choice of anterior and posterior tectum, and upon seeing that temporal axons preferred to grow on anterior rather than posterior tectal membranes, Bonhoeffer proposed, counterintuitively, that the mapping on the tectum by retinal axons was mediated in part by inhibition of axon advance (Baier and Bonhoeffer, 1992). Shortly thereafter, in the early 90s, John Flanagan told Bonhoeffer he knew of a tyrosine kinase that could be arrayed in just the kind of gradients Bonhoeffer envisioned. Bonhoeffer had already isolated a candidate factor from the tectum that was a ligand for Eph receptor tyrosine kinases. Both groups then converged to show that Eph receptors are arrayed in a gradient in the retina such that retinal cells from areas expressing high receptor terminated in regions of the tectum where the expression of ephrin ligands is low (Cheng et al., 1995; Drescher et al., 1995). These inhibitory interactions thus enable retinal axons to topographically map onto the tectum, and now we know, other brain regions (Feldheim et al., 1998). This work constituted a huge paradigm shift in the field of axon guidance and targeting, supporting Sperry's idea of chemoaffinity, broadly speaking, but through growth cone detection of ephrin gradients in the different axes of the tectum (Clandinin and Feldheim, 2009).

An old concept of specificity has returned of late, but not as Sperry might have imagined. The process of bundling or fasciculation of like axons, a seemingly innocuous act, may facilitate precise targeting. In the olfactory system, a tight correlation between the type of odorant receptor expressed by olfactory epithelial cell axons and the glomeruli they innervate led to the idea that the olfactory receptor itself serves as a guidance or axon-target matching molecule (Mombaerts et al., 1996; Barnea et al., 2004). In both the mouse olfactory system and in the fly eye and olfactory system, orderly fasciculation of axons bound for the same target occurs en route to targets and is required for proper connectivity at the end of the line, with adhesion molecules DS-CAM and cadherins in the fly eye serving this purpose (Clandinin and Feldheim, 2009; Imai et al., 2009).

The field is in the exciting position to decide whether afferenttarget connections form through a specific lock-and-key type molecular system, or a more coarse-grained orienting system of interleaving gradients read by growth cones as a first set of orienting cues, followed by adhesion and reorganization of axons en route and other factors that indicate a more precise position on the target map.

\section{Cultivation and pruning}

In the 70s, we were puzzled by why so many more cells were produced, in, say, the retina, than survived to adulthood (Buss et al., 2006). Then it was proposed that the determinant of whether a neuron lives or dies was the production of trophic factors, supplied by the target innervated by those axons.

By 1969, the legacy of the Levi-Montalcini and Hamburger work on trophic factors, specifically, nerve growth factor (NGF), became the bedrock for the concept of trophic support (Cowan, 2001). Injection of the "nerve growth-promoting factor" into the embryo caused overgrowth of sympathetic and sensory ganglia, an antiserum against this factor destroyed most cells in these ganglia, and this factor, named Nerve Growth Factor (NGF), was essential for their survival when placed in culture. In vivo, the target supplies neurotrophins, which activate Trk receptors on axons (Patapoutian and Reichardt, 2001). In the late 80s and 90s, other neurotrophins such as NT3, NT4, and BDNF were identified, along with their receptors and coreceptors, and downstream signaling and transcriptional events were highlighted (Greene and Angelastro, 2005). Most compelling was the finding that growth factor receptors, such as $\mathrm{p} 75$, can act either in survival or death pathways (Haase et al., 2008).

In the 70s we knew that single immature muscles were innervated by multiple axons, and that that the pattern of one afferent to a single motor fiber develops by the elimination of all but one axon. Refinement of exuberant axonal connections by elimination of collaterals was also demonstrated in the CNS (Cowan et al., 1984). Several climbing fiber axons extend onto single Purkinje cells during development, then pare back and focus on one Purkinje cell as they climb up its dendritic tree. At the same time that the extra axons are withdrawn, the axon that stays in place arborizes and makes more synapses (Kano and Hashimoto, 2009). Not surprisingly, axon and synapse elimination seems to rely on mechanisms used in cellular degradation processes (Luo and O'Leary, 2005; Song et al., 2008).

\section{Neural activity - and competition for the prize}

In addition to Sperry's notion of chemical labels for synapse specificity, another potent undercurrent that has fueled developmental studies of late stemmed from Hubel and Wiesel's work in the 50s through the late 70s (Daw, 2009) that the pattern and extent of sensory experience early in life molds connectivity. How does this work? Afferents from each eye project onto cells of the lateral geniculate nucleus (LGN) in the thalamus, and LGN cells project to layer IV of visual cortex, such that inputs from the right or left eye terminate in eye-specific layers in the LGN and columns in the cortex. As shown by physiological and anatomical studies using tracers and Golgi impregnation (LeVay et al., 1978), there is considerable overlap in the innervation from each eye onto target cells during development. After the eyes open, neural activity causes eye-specific arbors to segregate from one another, but if an eye is occluded as in Hubel and Wiesel's experiments, particularly during a critical period of several postnatal weeks in kittens (Wiesel and Hubel, 1965), connections from the open eye expand and dominate the physiology of cells in the visual cortex.

The idea that neural activity drives refinement and segregation of axons from different inputs was fueled by experiments by Bill Harris, who continued a line of experiments started by Tweetie years before on parabiosis of axolotls and newts (Harris, 1984). When Harris injected tetrodotoxin into the eye, he found that the silenced axons still grew to targets, but the axons did not refine their projections to their proper territories. Work on the neuromuscular junction, autonomic ganglia, climbing fibers, and visual pathways (LGN, tectum, and cortex) fortified the concept of competition between axons with different activity patterns, in adjusting their terminations in the target. Then in late $70 \mathrm{~s}$, in a seemingly odd experiment, Martha Constantine-Paton surgically added an eye near the tectum of the frog, and showed that fibers from the third eye and normal eye formed alternating columns in the tectum. These columns did not form if NMDA receptors were blocked, confirming the relevance of neural activity to the competition directing these innervation patterns (Constantine-Paton et al., 1990).

This work set the stage for enormous outpouring in the last $10-15$ years on the role neural activity plays in modulating connectivity, and how it interfaces with Sperry's notion of chemical labels in refinement of connectivity. And the notion of "use it or 
lose it" based on Hebb's hypothesis was extended to the idea that winning a competition with inputs that fired less frequently was enabled by uptake of growth factors from the target. To this day, there is argument over whether the prize in this competition is retrogradely supplied neurotrophins, such that the more active the terminal is, the more trophic substances come back to it. Whether this loop determines who wins, or whether neurotrophins are important for further aspects of winning, such as enhanced arborization, is still being contested (Kaneko et al., 2008).

Although the idea of a critical period for these effects is still central to our thinking of developmental plasticity, another set of findings upended our concepts on the role of neural activity. Waves of activity are prominent in the prenatal retina (Torborg and Feller, 2005), indicating that intrinsic activity plays a role at earlier stages of development, even if sensory activity does not emanate from external environment (Hanson et al., 2008). A debate ensued thereafter on whether activity is the sole influence on afferent-specific innervation or whether molecular cues also participate (Katz and Shatz, 1996). Few now doubt the existence of early waves of activity, but disagreement still abounds over the required features for waves to be instructive during refinement (Chalupa, 2009; Feller, 2009). Most would now agree, however, that molecular factors and activity both contribute to the development of targeting and segregation of different afferent populations (Huberman et al., 2008). The question is how: is there simply competition for retrograde growth factors? Does activity consolidate expression of guidance or pruning molecules? Does activity have any influence on the genes regulating axon withdrawal or modulation of expression of trophic factors? And is the chief molecular component aside from activity a guidance or matching molecule, or factors involved in intracellular signaling systems (Nicol et al., 2007)?

\section{Plasticity}

In the 70s, we understood that the maturing nervous system is capable of plasticity. Among the surprising findings on developmental plasticity in recent years is that inhibition plays a role during the critical period as circuits are set and become increasingly difficult to modify by alteration of sensory input. A growing list of factors are proposed to dampen the state of structural plasticity, including local inhibitory synapses and later-developing interneurons (Morishita and Hensch, 2008), Nogo, an oligodendrocytederived myelin protein that inhibits regenerating axons (McGee et al., 2005), PirB, a major histocompatability complex 1 receptor that interacts with the Nogo receptor (Syken et al., 2006), and chondroitin sulfate proteoglycans (Pizzorusso et al., 2006). If any of these factors are inhibited later, the mature cortex can revert to a more plastic state. Adult neurogenesis is an unexpected bonus to adult plasticity in that neurogenesis in the adult can be influenced by extrinsic factors such as exercise (Suh et al., 2009), pharmacological agents such as anti-depressants (Santarelli et al., 2003); and extrinsic influences can modulate neurogenesis by epigenetic mechanisms (Ma et al., 2009).

\section{Behavior - circuits working together}

Analysis of the development of behavior has progressed in some interesting directions in the last few years. In the 70s much effort was put into understanding hormonal control of anatomy and other sexually dimorphic differences. A strong thread over the last decades has been the study of the development of birdsong, founded on the work of Marler, Konishi, and Nottebohm (Marler and Peters, 1977; Gurney and Konishi, 1980; Nottebohm, 1981), and how the underlying circuitry functions during song learning (Woolley and Doupe, 2008). Noteworthy directions in the anal- ysis of circuits in behavior include: When barn owls have abnormal visual and auditory experiences in their critical period, anatomical projections also become abnormal, but persist long after normal input is restored. If abnormal sensory conditions are reinstated, then the shift in neural responses occurs more rapidly, indicating that maintaining the trace of the circuitry underlying the abnormal response facilitates readaptation in later life to abnormal sensory experiences (Linkenhoker et al., 2005). Studies on simple invertebrate systems, e.g., on the circuitry involving identified cells for olfactory behaviors in the worm (Chalasani et al., 2007), offer an exciting path to understanding how neural circuits underlying behavior unfold.

\section{When things go wrong: what have we learned from developmental studies?}

Injury and regeneration

One of the biggest paradigm shifts over the past few decades has been in our thinking about regeneration. From the days of Cajal until about a decade ago, we believed that peripheral axons can regrow to their proper destination, whereas mammalian CNS axons cannot. In the 70s Albert Aguayo's work gave a great boost to the field when he showed that a cut optic nerve would not only growth through a length of peripheral nerve graft but also make connections that relayed visual signals (Vidal-Sanz et al., 1987). This work led to two streams of investigation, the second rather unresolved to this day: First, while mature axons can regrow, they do so at a disappointingly slow rate, and they lack the molecular components of young growing axons. Now we know that molecular brakes preventing mature axon regrowth include repressors of the m-TOR pathway, cAMP, and other transcription factors (Hannila and Filbin, 2008; Park et al., 2008). Second, we have long known that the environment of the site of injury, adult neuropil, and tracts are rife with glia that impede regrowth. Activated macrophages aggressively induce retraction of dystrophic axons (Busch et al., 2009). Enormous effort went into purifying and cloning the elements in myelin that inhibit axon growth and generating mice lacking them (Schwab, 2004), but after several years of these investigations, the extent of axon regeneration after these molecules are disabled remains minimal. Perhaps the secret to successful regeneration is to re-empower older axons with the molecular programs that support axon growth, an ongoing attempt since the 80s (Skene, 1989).

\section{Neurodevelopmental disorders}

Forty years ago, most neurodevelopmental disorders were recorded in neuropathology handbooks or in psychiatrists' annals. But in the late 80 s and early 90 s, genetic analysis of humans with brain malformations and their families led to identification of mutated genes. Modeling of these genes in mice is still yielding insights into the cellular perturbations in the developing brain caused by these mutations ( $\mathrm{Li}$ et al., 2008). Most promising has been the identification of mutations in individuals with autism and schizophrenia. From studying the genes implicated in autism that encode synaptic adhesion molecules, insight has come into the crucial balance of inhibitory and excitatory synapses required for normal brain function (Chih et al., 2004; Südhof, 2008) and genes that control activity-dependent synapse development (Flavell and Greenberg, 2008). But linking these studies to the human brain has been tricky, because postmortem analyses do not allow biochemical or fine structural studies. Nonetheless, imaging studies have revealed that myelination is perturbed in autism (Herbert et al., 2004), supporting the idea that perturbed connectivity causes the devastating behavioral effects associated with the 
autism spectrum disorders. We desperately need good rodent models that mirror both structural and behavioral features of these diseases.

\section{Neurodegeneration}

Perhaps one of the most stunning advances toward allaying neurodegenerative diseases has come from an understanding of the sequence of gene activation and repression in programs of cell fate specification. Identification of these genes provides the ability to push cells toward a certain fate in vitro, transplant them into animals, and achieve successful growth and integration (Wichterle et al., 2002). This knowledge was used to manner strategies for human disease. Pluripotent stem (iPS) cells taken from an elderly patient with familial amyotrophic lateral sclerosis (ALS) were induced to form embryonic stem cells and using the known directives for producing motor neurons, these iPS cells were differentiated into motor neurons (Dimos et al., 2008). This approach facilitates the production of large numbers of cells with the patient's precise genotype, and suggests that age and disease did not prevent differentiation toward the desired cell type. Thus, basic research on genes controlling cell fate contributed to possible cell replacement therapy and molecular screening of motor neurons generated from iPS cells, especially from individuals with sporadic forms of ALS where the disrupted genes or influences on the disease are not known.

\section{Through the looking glass}

So much has transpired in unraveling events, many counterintuitive, during development. What is there that we look forward to? In distinguishing the roles played by molecular factors, from morphogens to transcription factors, we can expect more studies to cover a greater span of developmental events. With the ability to fate map and turn on genes at different times, we can learn how turning on one gene can affect multiple processes, from the transcription factors controlling specificity and fate, to molecules that direct axonal and dendritic growth and branching, to the factors regulating target selection, innervation, and refinement of connections. We will hear of more instances in which the same molecule is used for quite different aspects of development. For example, FGFs regulate transcription factors that mediate graded guidance factor expression in the midbrain and optic tectum, and they also modulate the tempo of radial glial cell differentiation to neuronal progenitors particularly in rostral cortex (Chen et al., 2009; Regan et al., 2009). Similarly, while morphogens such as BMPs and Wnts hold a prominent place in stimulating neural induction, they also serve as inhibitory axon guidance molecules (Butler and Dodd, 2003), and as modulators of synaptic growth (McCabe et al., 2004). We will undoubtedly see more surprising instances in which molecular factors function opposite to their canonical role. We were startled to learn that transcription factors such as engrailed- 2 and Otx- 2 can be released across synapses and act as either guidance or differentiation factors in cells that take them up (Brunet et al., 2005; Sugiyama et al., 2008). Are these oddities, or just the first examples?

Many of the new molecular genetic labeling techniques, such as transneuronal labeling with pseudorabies virus or photoactivatable compounds that block activity, are being used to explore mature circuitry across mono- or multisynaptic links (Luo et al., 2008). Down the road, we can expect these approaches to delineate afferent-target interactions during development, and to measure activity changes during different phases of development. We should grab the opportunity to reveal the dynamics of cellular and circuit development made possible by fate mapping and other genetic marking techniques together with our powerful imaging and computational arsenal. But we need more troops to analyze and mine these models and approaches. Journals and funding agencies need to better appreciate the inherent value in "descriptive" cellular anatomy and to support these much-needed investigations, performed so gloriously by too few (Morgan et al., 2005; Lu et al., 2009).

We can look forward to greater crossover of widely different disciplines: the discovery that the effects of antidepressants depend on adult neurogenesis (Santarelli et al., 2003) was based on analysis reliant on neuropharmacology, developmental neurobiology, mouse behavior, and molecular genetics. Our graduate programs must ensure that the next generation is trained in a spectrum of areas.

Recent interest in theory and computational modeling of neuronal networks has yielded many superb studies of function and circuit analysis across species (Marder and Bucher, 2007; Sussillo and Abbott, 2009) and behaviors. However, since the 70s and 80s (Whitelaw and Cowan, 1981), there have been only a few attempts at computational modeling of neural development (Miller, 1994; Simpson et al., 2009). As more students are entering programs in neuroscience aiming to participate in neural theory, we can look to them for help in modeling how neural development proceeds. In recent years, we have focused on individual subroutines - one part of a trajectory or a small set of molecules. In the coming years, we will need to catalog and then decipher how the vast number of factors are integrated during a single axon pathfinding decision, and how the full script of transcription factors and guidance factors that participate during the entire journey of a group of axons is played out.

Can we expect to understand how specific neural connections are established? My guess is yes. All roads point to a combination of the labeled pathway hypothesis, with cell adhesion molecules and fasciculation playing a more prominent role in conjoining growing axons with shared topographic origin as they grow, so that they all convene in specific target zones. We can compare this mechanism to the still-operative idea that axons home in on the target subdivisions by reading gradients, and recognize the finish line by reading cues on target cells, and we should then be able to test whether a "lock and key" molecular matching mechanism truly "seals the deal." We will also surely learn how and over what time period activity comes into play, and determine whether activity modulates guidance and other molecules.

How do we go forth? We can try to emerge from our villages of one-gene, one-process analysis and combine our current strengths with the legacy of neuroscientists who worked before the molecular revolution. We can take inspiration from our history, and bring back observational studies, training our students in the skills of developmental biologists and embryologists. As when revisiting a favorite vacation spot, we can return to the histogenetic approach to study brain development; there is so much more to learn and see. We can use the new ways of tracing and observing dynamics to study cell behavior in the neurons' natural habitat, with and without perturbations. We can look at the steps in the developmental dances, and try to divine how much is scripted and how much is trial and error. We must ask how the many factors that are expressed at the same time and place might act in concert, then use the new experimental approaches to deduce function. And finally, we should apply our computational power to understand the orchestration of cellular processes and signals that sculpt the emerging brain. Go, students, go! 


\section{References}

Attardi DG, Sperry RW (1963) Preferential selection of central pathways by regenerating optic fibers. Exp Neurol 7:46-64.

Baier H, Bonhoeffer F (1992) Axon guidance by gradients of a targetderived component. Science 255:472-475.

Barnea G, O'Donnell S, Mancia F, Sun X, Nemes A, Mendelsohn M, Axel R (2004) Odorant receptors on axon termini in the brain. Science 304:1468.

Bechara A, Falk J, Moret F, Castellani V (2007) Modulation of semaphorin signaling by Ig superfamily cell adhesion molecules. Adv Exp Med Biol 600:61-72.

Bonhoeffer T, Yuste R (2002) Spine motility. Phenomenology, mechanisms, and function. Neuron 35:1019-1027.

Brunet I, Weinl C, Piper M, Trembleau A, Volovitch M, Harris W, Prochiantz A, Holt C (2005) The transcription factor Engrailed-2 guides retinal axons. Nature 438:94-98.

Busch SA, Horn KP, Silver DJ, Silver J (2009) Overcoming macrophagemediated axonal dieback following CNS injury. J Neurosci 29:9967-9976.

Buss RR, Sun W, Oppenheim RW (2006) Adaptive roles of programmed cell death during nervous system development. Annu Rev Neurosci 29:1-35.

Butler SJ, Dodd J (2003) A role for BMP heterodimers in roof platemediated repulsion of commissural axons. Neuron 38:389-401.

Butt SJ, Fuccillo M, Nery S, Noctor S, Kriegstein A, Corbin JG, Fishell G (2005) The temporal and spatial origins of cortical interneurons predict their physiological subtype. Neuron 48:591-604.

Caudy M, Bentley D (1986) Pioneer growth cone steering along a series of neuronal and non-neuronal cues of different affinities. J Neurosci 6:1781-1795.

Chalasani SH, Sabelko KA, Sunshine MJ, Littman DR, Raper JA (2003) A chemokine, SDF-1, reduces the effectiveness of multiple axonal repellents and is required for normal axon pathfinding. J Neurosci 23:1360-1371.

Chalasani SH, Chronis N, Tsunozaki M, Gray JM, Ramot D, Goodman MB, Bargmann CI (2007) Dissecting a circuit for olfactory behaviour in Caenorhabditis elegans. Nature 450:63-70.

Chalupa LM (2009) Retinal waves are unlikely to instruct the formation of eye-specific retinogeniculate projections. Neural Dev 4:25.

Chen Y, Mohammadi M, Flanagan JG (2009) Graded levels of FGF protein span the midbrain and can instruct graded induction and repression of neural mapping labels. Neuron 62:773-780.

Cheng HJ, Nakamoto M, Bergemann AD, Flanagan JG (1995) Complementary gradients in expression and binding of ELF-1 and Mek4 in development of the topographic retinotectal projection map. Cell 82:371-381.

Cheng LC, Pastrana E, Tavazoie M, Doetsch F (2009) miR-124 regulates adult neurogenesis in the subventricular zone stem cell niche. Nat Neurosci 12:399-408.

Chih B, Afridi SK, Clark L, Scheiffele P (2004) Disorder-associated mutations lead to functional inactivation of neuroligins. Hum Mol Genet 13:1471-1477.

Clandinin TR, Feldheim DA (2009) Making a visual map: mechanisms and molecules. Curr Opin Neurobiol 19:174-180.

Constantine-Paton M, Cline HT, Debski E (1990) Patterned activity, synaptic convergence, and the NMDA receptor in developing visual pathways. Annu Rev Neurosci 13:129-154.

Corriveau RA, Huh GS, Shatz CJ (1998) Regulation of class I MHC gene expression in the developing and mature CNS by neural activity. Neuron 21:505-520.

Corty MM, Matthews BJ, Grueber WB (2009) Molecules and mechanisms of dendrite development in Drosophila. Development 136:1049-1061.

Cowan WM (1998) The emergence of modern neuroanatomy and developmental neurobiology. Neuron 20:413-426.

Cowan WM (2001) Viktor Hamburger and Rita Levi-Montalcini: the path to the discovery of nerve growth factor. Annu Rev Neurosci 24:551-600.

Cowan WM, Fawcett JW, O'Leary DD, Stanfield BB (1984) Regressive events in neurogenesis. Science 225:1258-1265.

Culotti JG (1994) Axon guidance mechanisms in Caenorhabditis elegans. Curr Opin Genet Dev 4:587-595.

Dasen JS, Jessell TM (2009) Hox networks and the origins of motor neuron diversity. Curr Top Dev Biol 88:169-200.

Daw NW (2009) The foundations of development and deprivation in the visual system. J Physiol 587:2769073.

Dickson BJ, Gilestro GF (2006) Regulation of commissural axon pathfinding by slit and its Robo receptors. Annu Rev Cell Dev Biol 22:651-675.
Dimos JT, Rodolfa KT, Niakan KK, Weisenthal LM, Mitsumoto H, Chung W, Croft GF, Saphier G, Leibel R, Goland R, Wichterle H, Henderson CE, Eggan K (2008) Induced pluripotent stem cells generated from patients with ALS can be differentiated into motor neurons. Science 321: $1218-1221$.

Doe CQ (1996) Asymmetric cell division and neurogenesis. Curr Opin Genet Dev 6:562-566.

Doetsch F, Caillé I, Lim DA, García-Verdugo JM, Alvarez-Buylla A (1999) Subventricular zone astrocytes are neural stem cells in the adult mammalian brain. Cell 97:703-716.

Dotti CG, Sullivan CA, Banker GA (1988) The establishment of polarity by hippocampal neurons in culture. J Neurosci 8:1454-1468.

Doyle JP, Dougherty JD, Heiman M, Schmidt EF, Stevens TR, Ma G, Bupp S, Shrestha P, Shah RD, Doughty ML, Gong S, Greengard P, Heintz N (2008) Application of a translational profiling approach for the comparative analysis of CNS cell types. Cell 135:749-762.

Drescher U, Kremoser C, Handwerker C, Loschinger J, Noda M, Bonhoeffer F (1995) In vitro guidance of retinal ganglion cell axons by RAGS, a 25 $\mathrm{kDa}$ tectal protein related to ligands for Eph receptor tyrosine kinases. Cell 82:359-370.

Easter SS Jr, Purves D, Rakic P, Spitzer NC (1985) The changing view of neural specificity. Science 230:507-511.

Edelman GM (1983) Cell adhesion molecules. Science 219:450-457.

Feldheim DA, Vanderhaeghen P, Hansen MJ, Frisén J, Lu Q, Barbacid M, Flanagan JG (1998) Topographic guidance labels in a sensory projection to the forebrain. Neuron 21:1303-1313.

Feller MB (2009) Retinal waves are likely to instruct the formation of eyespecific retinogeniculate projections. Neural Dev 4:24.

Fischbach GD, Frank E, Jessell TM, Rubin LL, Schuetze SM (1978) Accumulation of acetylcholine receptors and acetylcholinesterase at newly formed nerve-muscle synapses. Pharmacol Rev 30:411-428.

Flames N, Hobert O (2009) Gene regulatory logic of dopamine neuron differentiation. Nature 458:885-889.

Flavell SW, Greenberg ME (2008) Signaling mechanisms linking neuronal activity to gene expression and plasticity of the nervous system. Annu Rev Neurosci 31:563-590.

Gaiano N, Fishell G (2002) The role of notch in promoting glial and neural stem cell fates. Annu Rev Neurosci 25:471-490.

Gaze RM, Jacobson M, Szekely G (1965) On the formation of connexions by compound eyes in Xenopus. J Physiol 176:409-417.

Gleeson JG, Lin PT, Flanagan LA, Walsh CA (1999) Doublecortin is a microtubule-associated protein and is expressed widely by migrating neurons. Neuron 23:257-271.

Godement P, Vanselow J, Thanos S, Bonhoeffer F (1987) A study in developing visual systems with a new method of staining neurones and their processes in fixed tissue. Development 101:697-713.

Godement P, Salaün J, Mason CA (1990) Retinal axon pathfinding in the optic chiasm: Divergence of crossed and uncrossed fibers. Neuron 5:173-186.

Godement P, Wang LC, Mason CA (1994) Retinal axon divergence in the optic chiasm: dynamics of growth cone behavior at the midline. J Neurosci 14:7024-7039.

Goodman CS, Bastiani MJ, Doe CQ, du Lac S, Helfand SL, Kuwada JY, Thomas JB (1984) Cell recognition during neuronal development. Science 225:1271-1279.

Grafstein B (2006) Roger Sperry: pioneer of neuronal specificity. J Neurophysiol 96:2827-2829.

Greene LA, Angelastro JM (2005) You can't go home again: transcriptionally driven alteration of cell signaling by NGF. Neurochem Res 30:1347-1352.

Guillery R, Mason C, Taylor J (1995) Developmental determinants at the mammalian optic chiasm. J Neurosci 15:4727-4737.

Guillery RW, Casagrande VA, Oberdorfer MD (1974) Congenitally abnormal vision in Siamese cats. Nature 252:195-199.

Gurney ME, Konishi M (1980) Hormone-induced sexual differentiation of brain and behavior in zebra finches. Science 208:1380-1383.

Haase G, Pettmann B, Raoul C, Henderson CE (2008) Signaling by death receptors in the nervous system. Curr Opin Neurobiol 18:284-291.

Hamburger V (1988) Ontogeny of neuroembryology. J Neurosci 8:3535-3540.

Hannila SS, Filbin MT (2008) The role of cyclic AMP signaling in promoting axonal regeneration after spinal cord injury. Exp Neurol 209:321-332. 
Hanson MG, Milner LD, Landmesser LT (2008) Spontaneous rhythmic activity in early chick spinal cord influences distinct motor axon pathfinding decisions. Brain Res Rev 57:77-85.

Harris WA (1984) Axonal pathfinding in the absence of normal pathways and impulse activity. J Neurosci 4:1153-1162.

Harris WA, Holt CE, Bonhoeffer F (1987) Retinal axons with and without their somata, growing to and arborizing in the tectum of frog embryos: a time-lapse video study of single fibers in vivo. Development 101:123-133.

Harrison R (1910) The outgrowth of the nerve fiber as a mode of protoplasmic movement. J Exp Zool 9:787-846.

Hatten ME, Liem RK, Mason CA (1986) Weaver mouse cerebellar granule neurons fail to migrate on wild-type astroglial processes in vitro. J Neurosci 6:2676-2683.

Heintz N (2001) BAC to the future: the use of bac transgenic mice for neuroscience research. Nat Rev Neurosci 2:861-870.

Hemmati-Brivanlou A, Melton D (1997) Vertebrate neural induction. Annu Rev Neurosci 20:43-60.

Herbert MR, Ziegler DA, Makris N, Filipek PA, Kemper TL, Normandin JJ, Sanders HA, Kennedy DN, Caviness VS Jr (2004) Localization of white matter volume increase in autism and developmental language disorder. Ann Neurol 55:530-540.

Herrera E, Brown L, Aruga J, Rachel RA, Dolen G, Mikoshiba K, Brown S, Mason CA (2003) Zic2 patterns binocular vision by specifying the uncrossed retinal projection. Cell 114:545-557.

Hockfield S (1987) A Mab to a unique cerebellar neuron generated by immunosuppression and rapid immunization. Science 237:67-70.

Holt CE, Bertsch TW, Ellis HM, Harris WA (1988) Cellular determination in the Xenopus retina is independent of lineage and birth date. Neuron $1: 15-26$.

Holtmaat A, Svoboda K (2009) Experience-dependent structural synaptic plasticity in the mammalian brain. Nat Rev Neurosci 10:647-658.

Huber AB, Kolodkin AL, Ginty DD, Cloutier JF (2003) Signaling at the growth cone: ligand-receptor complexes and the control of axon growth and guidance. Annu Rev Neurosci 26:509-563.

Huberman AD, Feller MB, Chapman B (2008) Mechanisms underlying development of visual maps and receptive fields. Annu Rev Neurosci 31:479-509.

Hume RI, Role LW, Fischbach GD (1983) Acetylcholine release from growth cones detected with patches of acetylcholine receptor-rich membranes. Nature 305:632-634.

Hutson LD, Chien CB (2002) Pathfinding and error correction by retinal axons: the role of astray/robo2. Neuron 33:205-217.

Imai T, Yamazaki T, Kobayakawa R, Kobayakawa K, Abe T, Suzuki M, Sakano H (2009) Pre-target axon sorting establishes the neural map topography. Science 325:585-590.

Jacobson M, Hirose G (1978) Origin of the retina from both sides of the embryonic brain: a contribution to the problem of crossing at the optic chiasma. Science 202:637-639.

Jessell TM (1988) Adhesion molecules and the hierarchy of neural development. Neuron 1:3-13.

Jessell TM (2000) Neuronal specification in the spinal cord: inductive signals and transcriptional codes. Nat Rev Genet 1:20-29.

Jessell TM, Sanes JR (2000) Development. The decade of the developing brain. Curr Opin Neurobiol 10:599-611.

Kaneko M, Hanover JL, England PM, Stryker MP (2008) TrkB kinase is required for recovery, but not loss, of cortical responses following monocular deprivation. Nat Neurosci 11:497-504.

Kano M, Hashimoto K (2009) Synapse elimination in the central nervous system. Curr Opin Neurobiol 19:154-161.

Kapfhammer JP, Raper JA (1987) Collapse of growth cone structure on contact with specific neurites in culture. J Neurosci 7:201-212.

Kaprielian Z, Patterson PH (1993) Surface and cytoskeletal markers of rostrocaudal position in the mammalian nervous system. J Neurosci 13:2495-2508.

Katz LC, Iarovici DM (1990) Green fluorescent latex microspheres: a new retrograde tracer. Neuroscience 34:511-520.

Katz LC, Shatz CJ (1996) Synaptic activity and the construction of cortical circuits. Science 274:1133-1138.

Kim N, Stiegler AL, Cameron TO, Hallock PT, Gomez AM, Huang JH, Hubbard SR, Dustin ML, Burden SJ (2008) Lrp4 is a receptor for Agrin and forms a complex with MuSK. Cell 135:334-342.

Kofuji P, Hofer M, Millen KJ, Millonig JH, Davidson N, Lester HA, Hatten
ME (1996) Functional analysis of the weaver mutant GIRK2 K+ channel and rescue of weaver granule cells. Neuron 16:941-952.

Kong JH, Fish DR, Rockhill RL, Masland RH (2005) Diversity of ganglion cells in the mouse retina: unsupervised morphological classification and its limits. J Comp Neurol 489:293-310.

Kriegstein A, Alvarez-Buylla A (2009) The glial nature of embryonic and adult neural stem cells. Annu Rev Neurosci 32:149-184.

Landmesser LT (1980) The generation of neuromuscular specificity. Annu Rev Neurosci 3:279-302.

Le Douarin NM, Renaud D, Teillet MA, Le Douarin GH (1975) Cholinergic differentiation of presumptive adrenergic neuroblasts in interspecific chimeras after heterotopic transplantations. Proc Natl Acad Sci U S A 72:728-732.

Leamey CA, Merlin S, Lattouf P, Sawatari A, Zhou X, Demel N, Glendining KA, Oohashi T, Sur M, Fässler R (2007) Ten_m3 regulates eye-specific patterning in the mammalian visual pathway and is required for binocular vision. PLoS Biol 5:e241.

Leone DP, Srinivasan K, Chen B, Alcamo E, McConnell SK (2008) The determination of projection neuron identity in the developing cerebral cortex. Curr Opin Neurobiol 18:28-35.

Letourneau PC (1975) Cell-to-substratum adhesion and guidance of axonal elongation. Dev Biol 44:92-101.

LeVay S, Stryker MP, Shatz CJ (1978) Ocular dominance columns and their development in layer IV of the cat's visual cortex: a quantitative study. J Comp Neurol 179:223-244.

Li S, Mo Z, Yang X, Price SM, Shen MM, Xiang M (2004) Foxn4 controls the genesis of amacrine and horizontal cells by retinal progenitors. Neuron 43:795-807.

Li S, Jin Z, Koirala S, Bu L, Xu L, Hynes RO, Walsh CA, Corfas G, Piao X (2008) GPR56 regulates pial basement membrane integrity and cortical lamination. J Neurosci 28:5817-5826.

Lin AC, Holt CE (2008) Function and regulation of local axonal translation. Curr Opin Neurobiol 18:60-68.

Linkenhoker BA, von der Ohe CG, Knudsen EI (2005) Anatomical traces of juvenile learning in the auditory system of adult barn owls. Nat Neurosci 8:93-98.

Livet J, Weissman TA, Kang H, Draft RW, Lu J, Bennis RA, Sanes JR, Lichtman JW (2007) Transgenic strategies for combinatorial expression of fluorescent proteins in the nervous system. Nature 450:56-62.

Lohmann C, Bonhoeffer T (2008) A role for local calcium signaling in rapid synaptic partner selection by dendritic filopodia. Neuron 59:253-260.

Lohof AM, Quillan M, Dan Y, Poo MM (1992) Asymmetric modulation of cytosolic cAMP activity induces growth cone turning. J Neurosci 12:1253-1261.

Lu J, Tapia JC, White OL, Lichtman JW (2009) The interscutularis muscle connectome. PLoS Biol 7:e32.

Luo L, O'Leary DD (2005) Axon retraction and degeneration in development and disease. Annu Rev Neurosci 28:127-156.

Luo L, Callaway EM, Svoboda K (2008) Genetic dissection of neural circuits. Neuron 57:634-660.

Luria V, Krawchuk D, Jessell TM, Laufer E, Kania A (2008) Specification of motor axon trajectory by ephrin-B:EphB signaling: symmetrical control of axonal patterning in the developing limb. Neuron 60:1039-1053.

Ma DK, Jang MH, Guo JU, Kitabatake Y, Chang ML, Pow-Anpongkul N, Flavell RA, Lu B, Ming GL, Song H (2009) Neuronal activity-induced Gadd45b promotes epigenetic DNA demethylation and adult neurogenesis. Science 323:1074-1077.

Marder E, Bucher D (2007) Understanding circuit dynamics using the stomatogastric nervous system of lobsters and crabs. Annu Rev Physiol 69:291-316.

Marler P, Peters S (1977) Selective vocal learning in a sparrow. Science 198:519-521.

Marrs GS, Green SH, Dailey ME (2001) Rapid formation and remodeling of postsynaptic densities in developing dendrites. Nat Neurosci 4:10061013.

Mason CA (1982a) Development of terminal arbors of retinogeniculate axons in the kitten. I. Light microscopical observations. Neuroscience 7:541-559.

Mason CA (1982b) Development of terminal arbors of retinogeniculate axons in the kitten. II. Electron microscopical observations. Neuroscience 7:561-582. 
McAllister AK, Katz LC, Lo DC (1999) Neurotrophins and synaptic plasticity. Annu Rev Neurosci 22:295-318.

McCabe BD, Hom S, Aberle H, Fetter RD, Marques G, Haerry TE, Wan H, O'Connor MB, Goodman CS, Haghighi AP (2004) Highwire regulates presynaptic BMP signaling essential for synaptic growth. Neuron 41:891-905.

McConnell SK (1988) Fates of visual cortical neurons in the ferret after isochronic and heterochronic transplantation. J Neurosci 8:945-974.

McGee AW, Yang Y, Fischer QS, Daw NW, Strittmatter SM (2005) Experience-driven plasticity of visual cortex limited by myelin and Nogo receptor. Science 309:2222-2226.

Miale IL, Sidman RL (1961) An autoradiographic analysis of histogenesis in the mouse cerebellum. Exp Neurol 4:277-296.

Miller KD (1994) Models of activity-dependent neural development. Prog Brain Res 102:303-318.

Miyoshi G, Fishell G (2006) Directing neuron-specific transgene expression in the mouse CNS. Curr Opin Neurobiol 16:577-584.

Mombaerts P, Wang F, Dulac C, Chao SK, Nemes A, Mendelsohn M, Edmondson J, Axel R (1996) Visualizing an olfactory sensory map. Cell 87:675-686.

Morgan J, Huckfeldt R, Wong RO (2005) Imaging techniques in retinal research. Exp Eye Res 80:297-306.

Morishita H, Hensch TK (2008) Critical period revisited: impact on vision. Curr Opin Neurobiol 18:101-107.

Moskal JR, Trisler D, Schneider MD, Nirenberg M (1986) Purification of a membrane protein distributed in a topographic gradient in chicken retina. Proc Natl Acad Sci U S A 83:4730-4733.

Nauta WJ (1993) Some early travails of tracing axonal pathways in the brain. J Neurosci 13:1337-1345

Nicol X, Voyatzis S, Muzerelle A, Narboux-Nême N, Südhof TC, Miles R, Gaspar P (2007) cAMP oscillations and retinal activity are permissive for ephrin signaling during the establishment of the retinotopic map. Nat Neurosci 10:340-347.

Noctor SC, Flint AC, Weissman TA, Dammerman RS, Kriegstein AR (2001) Neurons derived from radial glial cells establish radial units in neocortex. Nature 409:714-720.

Nottebohm F (1981) A brain for all seasons: cyclical anatomical changes in song control nuclei of the canary brain. Science 214:1368-1370.

O'Leary DD, Chou SJ, Sahara S (2007) Area patterning of the mammalian cortex. Neuron 56:252-269.

Park KK, Liu K, Hu Y, Smith PD, Wang C, Cai B, Xu B, Connolly L, Kramvis I, Sahin M, He Z (2008) Promoting axon regeneration in the adult CNS by modulation of the PTEN/mTOR pathway. Science 322:963-966.

Patapoutian A, Reichardt LF (2001) Trk receptors: mediators of neurotrophin action. Curr Opin Neurobiol 11:272-280.

Patterson PH (1988) On the importance of being inhibited, or saying no to growth cones. Neuron 1:263-267.

Patterson P, Purves D (1982) Readings in developmental neurobiology. Cold Spring Harbor, NY: Cold Spring Harbor Laboratory.

Pizzorusso T, Medini P, Landi S, Baldini S, Berardi N, Maffei L (2006) Structural and functional recovery from early monocular deprivation in adult rats. Proc Natl Acad Sci U S A 103:8517-8522.

Polleux F, Ghosh A (2002) The slice overlay assay: a versatile tool to study the influence of extracellular signals on neuronal development. Sci STKE 2002:PL9.

Polleux F, Ince-Dunn G, Ghosh A (2007) Transcriptional regulation of vertebrate axon guidance and synapse formation. Nat Rev Neurosci 8:331-340

Purpura DP (1974) Dendritic spine "dysgenesis" and mental retardation. Science 186:1126-1128.

Qiu Z, Ghosh A (2008) A brief history of neuronal gene expression: regulatory mechanisms and cellular consequences. Neuron 60:449-455.

Rakic P, Sidman RL (1973) Sequence of developmental abnormalities leading to granule cell deficit in cerebellar cortex of weaver mutant mice. J Comp Neurol 152:103-132.

Ramon y Cajal S (1911) Histologie du systeme nerveux de l'homme et des vertebres. Paris: Maloine.

Regan JC, Concha ML, Roussigne M, Russell C, Wilson SW (2009) An Fgf8dependent bistable cell migratory event establishes CNS asymmetry. Neuron 61:27-34.

Reichardt LF (1984) Immunological approaches to the nervous system. Science 225:1294-1299.
Reichardt LF (1985) Developmental neurobiology: molecular bases of neural development. Science 229:1257-1258.

Rubenstein JL, Martinez S, Shimamura K, Puelles L (1994) The embryonic vertebrate forebrain: the prosomeric model. Science 266:578-580.

Sanchez-Camacho C, Bovolenta P (2008) Autonomous and nonautonomous Shh signalling mediate the in vivo growth and guidance of mouse retinal ganglion cell axons. Development 135:3531-3541.

Sanes DH, Reh TA, Harris WA (2006) Development of the nervous system. New York: Elsevier-Academic.

Sanes JR, Lichtman JW (2001) Induction, assembly, maturation and maintenance of a postsynaptic apparatus. Nat Rev Neurosci 2:791-805.

Santarelli L, Saxe M, Gross C, Surget A, Battaglia F, Dulawa S, Weisstaub N, Lee J, Duman R, Arancio O, Belzung C, Hen R (2003) Requirement of hippocampal neurogenesis for the behavioral effects of antidepressants. Science 301:805-809.

Sauer FC (1935) Mitosis in the neural tube. J Comp Neurol 62:377-405.

Scheiffele P, Fan J, Choih J, Fetter R, Serafini T (2000) Neuroligin expressed in nonneuronal cells triggers presynaptic development in contacting axons. Cell 101:657-669.

Schwab ME (2004) Nogo and axon regeneration. Curr Opin Neurobiol 14:118-124.

Serafini T, Kennedy TE, Galko MJ, Mirzayan C, Jessell TM, Tessier-Lavigne M (1994) The netrins define a family of axon outgrowth-promoting proteins homologous to C. elegans UNC-6. Cell 78:409-424.

Shen W, Da Silva JS, He H, Cline HT (2009) Type A GABA-receptordependent synaptic transmission sculpts dendritic arbor structure in Xenopus tadpoles in vivo. J Neurosci 29:5032-5043.

Sillitoe RV, Joyner AL (2007) Morphology, molecular codes, and circuitry produce the three-dimensional complexity of the cerebellum. Annu Rev Cell Dev Biol 23:549-577.

Simpson HD, Mortimer D, Goodhill GJ (2009) Theoretical models of neural circuit development. Curr Top Dev Biol 87:1-51.

Singer M, Nordlander RH, Egar M (1979) Axonal guidance during embryogenesis and regeneration in the spinal cord of the newt: the blueprint hypothesis of neuronal pathway patterning. J Comp Neurol 185:1-21.

Skene JH (1989) Axonal growth-associated proteins. Annu Rev Neurosci 12:127-156.

Solecki DJ, Trivedi N, Govek EE, Kerekes RA, Gleason SS, Hatten ME (2009) Myosin II motors and F-actin dynamics drive the coordinated movement of the centrosome and soma during CNS glial-guided neuronal migration. Neuron 63:63-80.

Song JW, Misgeld T, Kang H, Knecht S, Lu J, Cao Y, Cotman SL, Bishop DL, Lichtman JW (2008) Lysosomal activity associated with developmental axon pruning. J Neurosci 28:8993-9001.

Speidel CC (1933) Studies of living nerves. II. Activities of ameboid growth cones, sheath cells, and myelin segments, as reealed by prolonged observation of individual nerve fibers in frog tadpoles. Am J Anat 52:1-79.

Sperry RW (1963) Chemoaffinity in the orderly growth of nerve fiber patterns and connections. Proc Natl Acad Sci U S A 50:703-710.

Stein E, Tessier-Lavigne M (2001) Hierarchical organization of guidance receptors: silencing of netrin attraction by slit through a Robo/DCC receptor complex. Science 291:1928-1938.

Südhof TC (2008) Neuroligins and neurexins link synaptic function to cognitive disease. Nature 455:903-911.

Sugino K, Hempel CM, Miller MN, Hattox AM, Shapiro P, Wu C, Huang ZJ, Nelson SB (2006) Molecular taxonomy of major neuronal classes in the adult mouse forebrain. Nat Neurosci 9:99-107.

Sugiyama S, Di Nardo AA, Aizawa S, Matsuo I, Volovitch M, Prochiantz A, Hensch TK (2008) Experience-dependent transfer of Otx2 homeoprotein into the visual cortex activates postnatal plasticity. Cell 134:508 -520.

Suh H, Deng W, Gage FH (2009) Signaling in adult neurogenesis. Annu Rev Cell Dev Biol. Advance online publication. Retrieved Sept. 23, 2009. doi:10.1146/annurev.cellbio.042308.113256.

Sussillo D, Abbott LF (2009) Generating coherent patterns of activity from chaotic neural networks. Neuron 63:544-557.

Syken J, Grandpre T, Kanold PO, Shatz CJ (2006) PirB restricts oculardominance plasticity in visual cortex. Science 313:1795-1800.

Takahashi T, Nowakowski RS, Caviness VS Jr (1996) The leaving or Q fraction of the murine cerebral proliferative epithelium: a general model of neocortical neuronogenesis. J Neurosci 16:6183-6196.

Tavazoie M, Van der Veken L, Silva-Vargas V, Louissaint M, Colonna L, Zaidi 
B, Garcia-Verdugo JM, Doetsch F (2008) A specialized vascular niche for adult neural stem cells. Cell Stem Cell 3:279-288.

Tennyson VM (1970) The fine structure of the axon and growth cone of the dorsal root neuroblast of the rabbit embryo. J Cell Biol 44:62-79.

Tessier-Lavigne M, Goodman CS (1996) The molecular biology of axon guidance. Science 274:1123-1133.

Tessier-Lavigne M, Placzek M, Lumsden AG, Dodd J, Jessell TM (1988) Chemotropic guidance of developing axons in the mammalian central nervous system. Nature 336:775-778.

Toni N, Laplagne DA, Zhao C, Lombardi G, Ribak CE, Gage FH, Schinder AF (2008) Neurons born in the adult dentate gyrus form functional synapses with target cells. Nat Neurosci 11:901-907.

Torborg CL, Feller MB (2005) Spontaneous patterned retinal activity and the refinement of retinal projections. Prog Neurobiol 76:213-235.

Tosney KW, Landmesser LT (1985) Specificity of early motoneuron growth cone outgrowth in the chick embryo. J Neurosci 5:2336-2344.

Trimarchi JM, Stadler MB, Cepko CL (2008) Individual retinal progenitor cells display extensive heterogeneity of gene expression. PLoS One 3:e1588.

Vidal-Sanz M, Bray GM, Villegas-Pérez MP, Thanos S, Aguayo AJ (1987) Axonal regeneration and synapse formation in the superior colliculus by retinal ganglion cells in the adult rat. J Neurosci 7:2894-2909.

Waites CL, Craig AM, Garner CC (2005) Mechanisms of vertebrate synaptogenesis. Annu Rev Neurosci 28:251-274.
Walsh C, Cepko CL (1988) Clonally related cortical cells show several migration patterns. Science 241:1342-1345.

Walter J, Kern-Veits B, Huf J, Stolze B, Bonhoeffer F (1987) Recognition of position-specific properties of tectal cell membranes by retinal axons in vitro. Development 101:685-696.

Watson FL, Heerssen HM, Bhattacharyya A, Klesse L, Lin MZ, Segal RA (2001) Neurotrophins use the Erk5 pathway to mediate a retrograde survival response. Nat Neurosci 4:981-988.

Whitelaw VA, Cowan JD (1981) Specificity and plasticity of retinotectal connections: a computational model. J Neurosci 1:1369-1387.

Wichterle H, Lieberam I, Porter JA, Jessell TM (2002) Directed differentiation of embryonic stem cells into motor neurons. Cell 110:385-397.

Wiesel TN, Hubel DH (1965) Comparison of the effects of unilateral and bilateral eye closure on cortical unit responses in kittens. J Neurophysiol 28:1029-1040.

Wilson SI, Shafer B, Lee KJ, Dodd J (2008) A molecular program for contralateral trajectory: Rig-1 control by LIM homeodomain transcription factors. Neuron 59:413-424.

Wolinsky EJ, Landis SC, Patterson PH (1985) Expression of noradrenergic and cholinergic traits by sympathetic neurons cultured without serum. J Neurosci 5:1497-1508.

Woolley SC, Doupe AJ (2008) Social context-induced song variation affects female behavior and gene expression. PLoS Biol 6:e62.

Yamagata M, Sanes JR (2008) Dscam and Sidekick proteins direct laminaspecific synaptic connections in vertebrate retina. Nature 451:465-469. 